\title{
Implementasi Keringanan Uang Kuliah Tunggal Bagi Mahasiswa di Era New Normal
}

\author{
Ikhwan Nur Rois ${ }^{1}$, Arrum Wijaya ${ }^{2}$, Afiffah Vinda Prananingrum ${ }^{3}$ \\ ${ }^{1}$ Sekolah Tinggi Agama Islam Masjid Syuhada Yogyakarta, \\ ${ }^{2}$ Institut Agama Islam Negeri Pekalongan, \\ ${ }^{3}$ Institut Agama Islam Negeri Surakarta \\ roisnur04@gmail.com
}

\begin{tabular}{l} 
Artikel \\
\hline Sejarah Artikel: \\
Diterima: Juli 2020 \\
Disetujui: September2020 \\
Dipublikasikan: September \\
2020 \\
\hline Kata kunci \\
Implementasi, Uang \\
Kuliah Tunggal, New \\
Normal, \\
Keywords: \\
Implementation, Single \\
Tuition Policy, New \\
Normal Era \\
\hline
\end{tabular}

\begin{abstract}
ABSTRAK
Pada era new normal ini pihak Kementerian Agama telah menerbitkan Keputusan Menteri Agama (KMA) No. 515 Tahun 2020 tentang keringanan uang kuliah tunggal (UKT) pada Perguruan Tinggi Keagamaan Islam Negeri (PTKIN) atas dampak bencana pandemi Covid-19 pada tanggal 12 Juni 2020. Keputusan tersebut pada implementasinya memberikan dampak yang signifikan bagi mahasiswa PTKIN, oleh karena itu penelitian ini bertujuan untuk mengetahui bagaimana implementasi keringanan uang kuliah tunggal bagi mahasiswa. Jenis penelitian ini berupa penelitian kualitatif dengan menggunakan metode kajian pustaka (libraty research) dan pendekatan historis dan kajian pustaka daring (elibrary research) yang mengkaji terkait topik yang relevan. Teknik pengumpulan data berupa dokumentasi dan wawancara. Hasil penelitian ini mengungkapkan bahwa proses terjadinya era new normal, proses implementasi keringanan uang kuliah tunggal bagi mahasiswa, dan dampak positif dan dampak negatif bagi mahasiswa PTKIN.
\end{abstract}

\section{ABSTRACT}

In this new normal era, the Ministry of Religion has issued Decree of the Minister of Religion (KMA) No. 515 of 2020 concerning the relief of single tuition (UKT) at the State Islamic Religious University (PTKIN) over the impact of the Covid-19 pandemic disaster on June 12, 2020. The decision on its implementation had a significant impact on PTKIN students, therefore this study aims to determine how the implementation of the Single Tuition Policy (UKT) for students. This type of research is in the form of qualitative research using library research methods (historical research) and historical approaches and online library studies (elibrary research) that examine relevant topics. Data collection techniques in the form of documentation and interviews. The results of this study reveal that the process of the occurrence of the new normal era, the process implementation of the Single Tuition Policy (UKT) for students, and the positive and negative impacts on PTKIN students.

(C) 2020 Ikhwan Nur Rois, Arrum Wijaya, Afiffah Vinda Prananingrum Under The License CC-BY SA 4.0

\section{PENDAHULUAN}

Semenjak virus coronavirus disease 2019 atau kita kenal dengan virus Covid-19 telah menjadikan keadaan dan kondisi pada dunia ini memburuk. Telah ditetapkan oleh pihak WHO (World Health Organization) pada tanggal 11 Februari 2020 (Zhao, Shi et al, 2020), bahwasanya wilayah yang pertama kali tersebarnya virus ini pada kota Wuhan, Provinsi 
Hubei, Tiongkok di bulan Desember 2019, pada awalnya virus ini tidaklah membuat keadaan dunia memburuk, akan tetapi berjalannya waktu, virus ini telah merambah ke beberapa wilayah bahkan Negara di beberapa benua, salah satunya benua Eropa dan benua Asia.

Sasaran utama Coronavirus ini (Covid-19) adalah sistem pernafasan pada manusia. Jika kita melihat sejar ah dimasa silam, wabah Coronavirus $(\mathrm{CoV})$ merupakan suatu sindrom pernafasan akut yang parah (SARS)-CoV (the severe acute respiratory syndrome (SARS)-CoV) dan sindrom pernafasan Timur Tengah (MERS)-CoV (the Middle East respiratory syndrome (MERS)-CoV) yang telah memiliki tanda sebelumnya menjadi ancaman kesehatan terbesar pada masyarakat (Rothan \& Byrareddy, 2020). Semenjak munculnya Covid-19 pertama kali di Wuhan, virus ini berawal dari endemi kemudian menjadi epidemi kemudian berubah status menjadi pandemi, yang mana pandemi ini sudah meliputi seluruh dunia.

Pada keadaan pandemi Covid-19 yang hingga sekarang dan tidak tahu sampai kapan semua ini berakhir, telah memberi dampak dari beberapa sektor di dunia termasuk di Indonesia. Salah satu sektor yang berdampak ialah sektor pendidikan di Indonesia, baik pendidikan dasar hingga perguruan tinggi, baik pendidikan negeri maupun swasta. Pada artikel ini akan kami bahas dampak yang terjadi pada perguruan tinggi keagamaan negeri (PTKIN) yang mengantisipasi kegiatan pembelajaran yang biasanya dilakukan secara tatap muka di ruang kelas beralih pada pembelajaran jarak jauh (PJJ) secara daring atau online (Rifki, 2020). Pembelajaran Jarak Jauh (PJJ) merupakan pembelajaran yang dilakukan guna mengantisipasi batasan waktu, jarak serta tempat tinggal ketika sedang melakukan proses pembelajaran. Adapun karakteristik dari PJJ ini yaitu seorang pendidik dan peserta didik tidak ada tatap muka secara langsung melainkan terpisah secara fisik dalam aktivitas pembelajarannya (Munir, 2009), oleh karena itu seluruh perguruan tinggi memilih untuk menerapkan pembelajaran ini selama pandemi Covid-19. Dalam pembelajarannya ini sangat membutuhkan peran dari media teknologi, seperti contohnya aplikasi zoom, lark meeting, google meet, classroom, dan aplikasi lainnya yang sedang tren di era pandemi seperti sekarang ini.

Adapun dampak lain yang diakibatkan dengan adanya Covid-19 adalah sektor ekonomi dari setiap masyarakat yang mengalami gangguan. Karena sebab itu, Kementrian Agama mengeluarkan Keputusan Menteri Agama (KMA) Nomor 515 Tahun 2020 yang berkaitan dengan Keringanan Uang Kuliah Tunggal untuk Perguruan Tinggi Keagamaan Negeri (PTKN) yang terdampak COVID-19, ditandatangani oleh Fachrul Razi (Menteri Agama Republik Indonesia), pada Jumat 12 Juni 2020. Setelah proses ditandatangani oleh Menteri Agama tersebut, maka forum Rektor PTKIN se-Indonesia mencoba untuk menerapkan pada setiap 
PTKIN yang dipimpinnya, alhasil keputusan tersebut banyak menimbulkan kontroversi di tengah para mahasiswanya.

Berdasarkan hasil Keputusan Menteri Agama tersebut bahwa banyak sektor-sektor yang berdampak, seperti: ekonomi, pendidikan maupun sosial yang dihasilkan, baik dampak positif ataupun negatif terhadap mahasiswa PTKIN seluruh Indonesia. Oleh karena itu, artikel ini bertujuan untuk implementasi KMA tersebut; 3) Bagaiamana dampak positif dan dampak negatif dari penerapan KMA tersebut bagi mahasiswa PTKIN.

\section{METODE PENELITIAN}

Jenis penelitian ini berupa penelitian kualitatif, suatu penelitian yang menganalisis atau mendeskripsikan suatu fenomena atau masalah yang terjadi, baik berupa peristiwa, dan aktifitas sosial. Peneliti menggunakan metode kajian pustaka (library research) dengan pendekatan historis yaitu suatu pendekatan yang menganalisis suatu fenomena berdasarkan proses kejadiannya dan pendekatan kajian pustaka daring (e-library research) yaitu suatu sistem yang mempunyai bermacam-macam layanan serta sumber informasi yang lebih mempermudah dalam mengaksesnya melalui perangkat digital (Sismanto dalam Cecep Kustandi dan Robinson Situmorang, 2013).

Sumber data pada penelitian ini merupakan subjek data-data yang valid dan relevan, yang mana teknik pengumpulan data primer dengan dokumentasi serta wawancara secara update dan online, serta data penguatnya atau sekunder dengan mencari sumber-sumber terkini, baik berupa: buku, berita, artikel, situs atau website. Adapun analisis data menggunakan reduksi data, penyajian data, serta penarikan kesimpulan. Setelah itu dilakukan pengecekan keabsahan data yang diperoleh dengan triangulasi, analisis kasus negatif, menggunakan bahan referensi, serta pengecekan anggota.

\section{HASIL PENELITIAN}

Pada bagian ini, kami akan memaparkan hasil penelitian artikel ini, yang mana terbagi menjadi 3 (tiga) sub bagian, diantaranya: 1) Proses terjadinya era new normal, 2) Proses implementasi KMA No. 515 Tahun 2020, dan 3) Dampak positif dan negatif bagi Mahasiswa PTKIN.

1) Proses terjadinya era new normal

Berdasarkan hasil penelitian yang telah dilakukan, maka dapat diperoleh proses penyebaran pandemi Covid-19 (Titik dan Hilmi, 2020) dan tahapan terjadinya era new normal (Nuh, 2020). Hasil kami akan sajikan berbentuk grafik dibawah ini: 


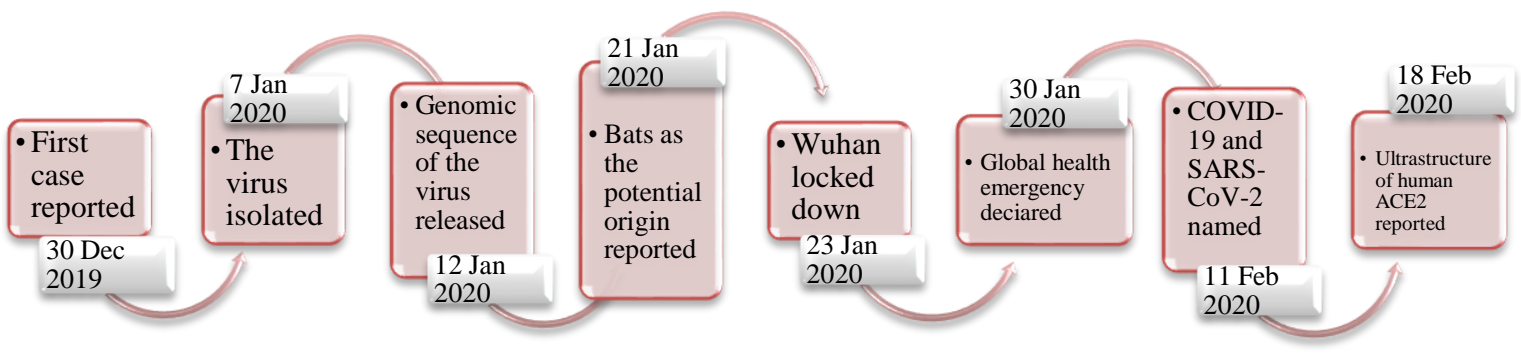

Grafik 1. Proses Penyebaran Pandemi Covid-19

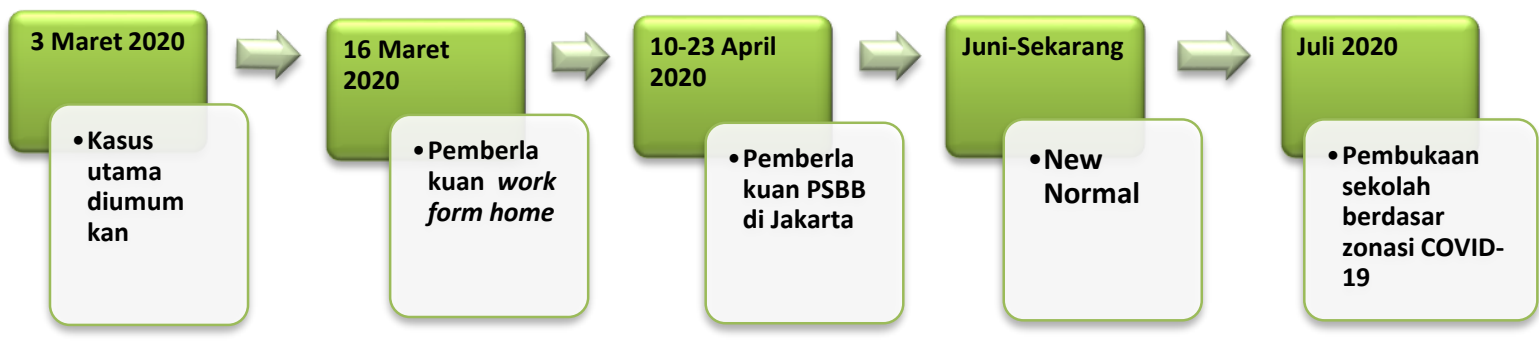

\section{Grafik 2. Tahapan Terjadinya Era New Normal}

2) Proses Implementasi Keringanan Uang Kuliah Tunggal.

Berdasarkan hasil penelitian yang telah dilakukan, bahwa proses implementasi penerapan keringanan uang kuliah tunggal bagi mahasiswa PTKIN di Indonesia berdasarkan keputusan Menteri Agama (KMA No. 515 Tahun 2020), maka dapat diperoleh dokumen KMA No. 515 Tahun 2020(Kementerian Agama, 2020). Hasil akan kami sajikan berbentuk tabel dibawah ini:

Tabel 1 KMA No. 515 Tahun 2020

\begin{tabular}{ll}
\hline Keputusan & Keterangan \\
\hline Kesatu & $\begin{array}{l}\text { Menetapkan keringanan UKT untuk mahasiswa Program } \\
\text { Diploma dan Sarjana pada PTKN atas dampak COVID- } \\
19 .\end{array}$ \\
Kedua & $\begin{array}{l}\text { Keringanan berupa pengurangan UKT atau perpanjangan } \\
\text { waktu pembayaran UKT. }\end{array}$ \\
\hline
\end{tabular}




\begin{tabular}{|c|c|}
\hline Ketiga & $\begin{array}{l}\text { Selain bentuk keringanan Diktum KEDUA, bagi PTKN } \\
\text { dapat menerapkan pola keuangan badan layanan umum, } \\
\text { keringanan berupa pembayaran UKT secara berangsur. }\end{array}$ \\
\hline Keempat & $\begin{array}{l}\text { Diberikan keringanan apabila mahasiswa memberikan } \\
\text { bukti status orang tua/wali; } \\
\text { a. Meninggal dunia } \\
\text { b. Mengalami pemutusan hubungan kerja } \\
\text { c. Mengalami kerugian usaha atau dinyatakan pailit } \\
\text { d. Mengalami penutupan tempaat usaha } \\
\text { e. Pendapatan menurun secara signifikan }\end{array}$ \\
\hline Kelima & $\begin{array}{l}\text { Keringanan UKT dilakukan dengan sistem dalam } \\
\text { jaringan (daring) atau luar jaringan (luring) }\end{array}$ \\
\hline Keenam & $\begin{array}{l}\text { Keringanan UKT berlaku untuk semester gasal Tahun } \\
\text { Akademik 2020/2021 dan akan dievaluasi dan } \\
\text { pemantauan sesuai dengan kebutuhan. }\end{array}$ \\
\hline Ketujuh & $\begin{array}{l}\text { Rektor PTKN menetapkan mekanisme pelaksanaan } \\
\text { keringanan UKT sebagaimana dimaksudkan pada Diktum } \\
\text { KESATU. }\end{array}$ \\
\hline Kedelapan & $\begin{array}{l}\text { Rektor dapat bekerjasama dengan pihak ketiga untuk } \\
\text { membantu pembiayaan UKT bagi mahasiswa }\end{array}$ \\
\hline Kesembilan & $\begin{array}{l}\text { Rektor melaporkan pelaksanaan keringanan UKT kepada } \\
\text { Direktur Jenderal paling lambat akhir semester berjalan. }\end{array}$ \\
\hline Kesempuluh & $\begin{array}{l}\text { Keputusan ini mulai berlaku pada tanggal ditetapkan, } \\
\text { yaitu } 12 \text { Juni } 2020 .\end{array}$ \\
\hline
\end{tabular}

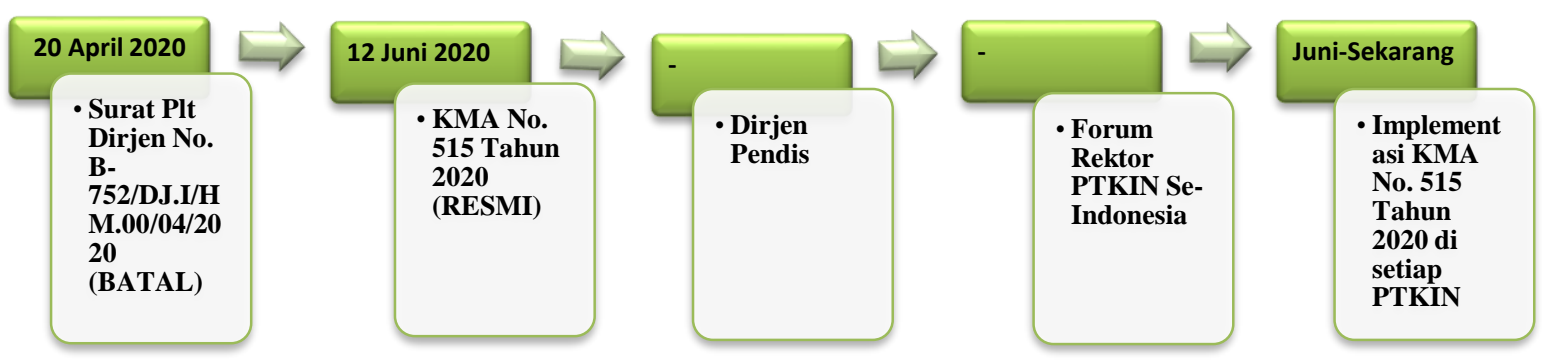

\section{Grafik 3. Implementasi UKT}

3) Dampak positif dan negatif bagi Mahasiswa PTKIN

Berdasarkan hasil penelitian yang telah dilakukan, maka dapat dilihat dari implementasi KMA No. 515 Tahun 2020 memberikan dampak positif dan negatif bagi para mahasiswa PTKIN. Hasil kami akan sajikan berbentuk tabel dibawah ini:

Tabel 2 Dampak Positif Bagi Mahasiswa PTKIN 


\begin{tabular}{ll}
\hline Poin & Dampak Positif \\
\hline A & $\begin{array}{l}\text { Mahasiswa dengan perekonomian rendah yang terdampak Covid-19 } \\
\text { terbantu. }\end{array}$ \\
B & $\begin{array}{l}\text { Pengalokasian dana yang seharusnya dianggarkan dari UKT dalam } \\
\text { sarana dan prasarana di kampus digunakan sesuai tujuannya. }\end{array}$ \\
C & Meringankan biaya studi di kampus \\
D & $\begin{array}{l}\text { Pembelajaran lebih rileks karena dilakukan di rumah masing- } \\
\text { masing sehingga leih nyaman sesuai standar kenyamanan }\end{array}$ \\
& mahasiswa. \\
\hline Poin & \multicolumn{1}{c}{ Mahasiswa PTKIN } \\
\hline A & $\begin{array}{l}\text { Syarat dan ketentuan keringanan hanya berlaku bagi pihak mahasiswa } \\
\text { yang terdampak Covid-19 dengan bukti surat PHK atau surat kematian } \\
\text { orang tua dari mahasiswa dan sejenisnya, padahal sebagian besar orang } \\
\text { tua atau wali mahasiswa bukan merupakan anak pegawai/ karyawan. }\end{array}$ \\
Fasilitas kampus yang seharusnya ditujukan untuk mahasiswa tidak \\
terpakai. \\
Prosedural pengajuan keringanan UKT yang cenderung rumit seperti \\
persyaratan hendak mendaftar ulang, membuat mahasiswa semakin \\
sulit. \\
Pembelajaran yang dilakukan serba daring akan membuat mahasiswa \\
semakin individualis, hal ini disebabkan karena jarak antar mahasiswa. \\
Pembelajaran yang bersifat praktik akan lebih sulit dilaksanakan. \\
Pembelajaran di rumah dinilai kurang efektif, karena tidak dapat \\
dijauhkan dari kesibukan pekerjaan di rumah masing-masing \\
mahasiswa.
\end{tabular}

\section{PEMBAHASAN}

Pada bagian pembahasan ini, kami akan memaparkan hasil penelitian dengan sebuah teori ataupun sumber relevan lainnya, yang mana akan terbagi menjadi 3 (tiga) sub pembahasan, diantaranya:

\section{Proses Terjadinya Era New Normal}

Era new normal ini terjadi tentunya melalui beberapa fase sebelumnya, diawali pada munculnya suatu wabah Covid-19 di kota Wuhan, China tersebut, oleh karena itu kami akan membahas hasil penelitian ini dengan 3 (tiga) fase, diantaranya:

A. Fase Awal Penyebaran Pandemi Covid-19 di Dunia 
Wang (2020) mengemukakan bahwa pandemi Covid-19 termasuk virus RNA strain tunggal positif yang tidak memiliki pigmen namun berkapsul. Virus ini termasuk golongan dari Coronaviridae yaitu ordo Nidovirales, yang memiliki struktur berbentuk layaknya kubus dengan protein $\mathrm{S}$ bertempat pada permukaan virus. Sedangkan arti dari Protein S (spike protein) yaitu jenis protein antigen yang paling menonjol dari virus yang berstruktur guna penulisan gen. Fungsi dari Protein $\mathrm{S}$ untuk menempelkan serta menjadi jalan masuk virus pada sel host (hubungan protein $\mathrm{S}$ bersama reseptor pada sel inang). Coronavirus memiliki sifat rentan dengan panas yang mana dapat dimatikan menggunakan desinfektan yang memiliki kandungan alkohol, detergen non-ionik, kloroform, formalin, oxidizing, asam perioksiasetat, eter, klorin, dan pelarut lipid bersuhu 56 derajat $\mathrm{C}$ dengan waktu 30 menit, sedangkan Klorheksidin tidak memiliki fungsi untuk mematikan virus (Yuliana, 2020).

Adapun kronologi penyebaran COVID-19 di Dunia ini diawali kasus penyebaran di Wuhan, China. Bermula pada Desember 2019 akhir, terdapat kelompok pasien rumah sakit di diagnosis awal terkena pneumonia akut dan mereka berkaitan dengan pasar grosir makanan basah hewan dan laut di Wuhan, Provinsi Hubei, China (Andrea, 2020). Pada tanggal 18 Desember 2019 hingga 29 Desember 2019 satu dari lima pasien sindrom gangguan pernafasan akut dari kelompok tersebut meninggal (Ren et al, 2020). Tanggal 2 Januari 2020, berjumlah 41 pasien rumah sakit dinyatakan terinfeksi oleh Covid-19, ada dari mereka memiliki riwayat penyakit kardiovaskular, hipertensi, dan diabetes (Chaolin et al, 2020). Kemudian tanggal 22 Januari 2020 diumumkan terdapat 571 kasus Covid-19 baru di 25 kota dan kabupaten di Tiongkok (Hongzhu, 2020). Dilaporkan oleh KKNC (Komisi Kesehatan Nasional China) dengan rincian 22 Januari 202017 kematian awal, berjumlah 1975 kasus pasti terinfeksi COVID-19 dengan total kematian 56 di daratan Tiongkok (Wang et al, 2020). Terdapat data lain bahwa pada 24 Januari 2020 diperkirakan menjadi 5502 kasus kejadian kumulatif di China (Hiroshi et al, 2020). Akhirnya tanggal 30 Januari 2020, jumlah pasti kasus Covid-19 di Cina sebagaimana yang dikatakan (Matteo et al, 2020) adalah 7734 serta 90 kasus serupa di berbagai negara seperti, Sri Lanka, Kanada, Firlandia, Prancis, Australia, Uni Emirat Arab, Republik Korea, Jepang, Taiwan, Nepal, Thailand, Vietnam, Jerman, Kamboja, Finlandia, dan Amerika Serikat. Dengan hitungan fatalitas kasus 2,2\% (170/7824). Setelah masuknya fase awal penyebaran di dunia ini, pandemi Covid-19 juga menyebar kasusnya di Indonesia.

B. Fase Awal Penyebaran Pandemi Covid-19 di Indonesia 
Pada 25 Maret 2020 kasus positif Covid-19 mencapai 414.179 diiringi angka kematian 18.440, jika dirata rata adalah 4,4\% dalam 192 negara, hal ini disampaikan oleh Kementrian Kesehatan Republik Indonesia dikutip dari WHO (World Health Organization). Adapun munculnya 2 kasus awal Covid-19 di Indonesia yaitu pada 2 Maret 2020 sampai 25 Maret 2020 total kasus positif hingga 790 dalam 24 provinsi, dan ,masih tetap mengalami peningkatan sampai sekarang. Kasus pandemi Covid-19 ini menimbulkan dampak yang sangat luar biasa di seluruh dunia, tidak hanya pada bidang kesehatan saja, tetapi berimbas juga di bidang sosial, perekonomian, pendidikan dan dalam bidang kehidupan yang lain. Hampir seluruh warga dunia begitupun dengan warga negara Indonesia diharuskan untuk melakukan seluruh kegiatan dari rumah (Titik \& Hilmi, 2020). Semakin cepat berkembang dan menyebarnya virus ini di Indonesia, mengakibatkan jumlah angka kematian yang terus melonjak sejak dilaporkan adanya kasus positif Covid-19 di bulan Maret awal 2020. Karena sebab itu Indonesia dikategorikan kedalam keadaan darurat nasional (Uswah et al, 2020).

Pada 9 April 2020, dilaporkan bahwa coronavirus telah merambah ke 34 provinsi di Indonesia, dalam data tercatat ada 3 provinsi paling parah yaitu Jawa Timur, DKI Jakarta, dan Sulawesi Selatan. Kemudian pada 26 Juni 2020 Jawa Timur dapat mengalahkan DKI Jakarta menduduki peringkat tertinggi sebagai provinsi yang sangat terdampak. Dan hingga sekarang 26 Juni 2020 Indonesia sudah tercatat 51.427 kasus positif paling banyak di Asia Tenggara melebihi Singapura, untuk jumlah kematian berada diposisi ke enam dengan angka 2.683 jiwa. Untuk angka yang telah sembuh berjumlah 21.333 dan sedang dirawat 27.411 kasus (Worldometer, 2020).

Sebelumnya pada Kamis, 19 Maret 2020 dari berita detiknews, Achmad Yurianto selaku juru bicara pemerintah (Team Gugus Tugas penanganan Covid-19) mengemukakan bahwasannya pemerintah sedang mengupayakan untuk diadakannya tes massal dan uji PCR virus Corona. Achmad juga menambahkan informasi resmi perkembangan Covid-19 bahwa penelitian WHO sampai saat ini, Kamis 19 Maret 2020 dibantu oleh seluruh ahli virus corona dunia,belum memperoleh kesepakatan yang dapat dijadikan tumpuan dunia untuk pengobatan Covid-19 (Yunus \& Rezki, 2020).

C. Fase New Normal

Dengan keadaan yang seperti ini, tentunya pemerintah Indonesia tidak bisa hanya diam saja, oleh sebab itu untuk mengatasi serta memutus rantai penyebaran dari virus Covid-19 pemerintah Indonesia menetapkan kebijakan dengan melakukan pembatasan 
kegiatan diluar rumah, bekerja di rumah (work from home), kegiatan belajar mengajar dan untuk beribadah juga dilakukan di rumah. Tujuan dari kebijakan tersebut semoga mampu memberikan solusi dari masalah yang sedang melanda negara Indonesia ini. Dan untuk mengetahui hasilnya dapat melihat dari apa yang akan terjadi setelah adanya kebijakan publik ini untuk bahan evaluasi ditetapkannya sebuah kebijakan. Bentuk dari kebijakan itu dapat dilihat dari adanya batasan batasan seperti, dibatasinya jumlah transportasi beserta jadwal operasinya, ditutupnya sebagian akses jalan pada waktu yang ditentukan, serta seluruh pekerjaan dilakukan dirumah, istilah kebijakan ini disebut dengan lockdown. Lockdown juga termasuk dalam aturan Undang Undang No 6 tahun 2018 kaitannya dengan Kekarantinaan Kesehatan di Pintu Masuk dan di Wilayah dilaksanakan dengan adanya acara pengamatan penyakit serta Faktor Resiko Kesehatan Masyarakat pada sarana angkut barang, orang atau lingkungan, dan tanggapan mengenai Kedaruratan Kesehatan Masyarakat berwujud Kekarantinaan Kesehatan (Yunus \& Rezki, 2020).

Tidak hanya itu saja, namun pemerintah juga memfasilitasi sebuah layanan khusus agar masyarakat dapat mengakses data terkait dengan coronavirus ini guna meminimalisir ketakutan masyarakat yang diakibatkan karena banyak beredarnya informasi informasi hoaks. Menurut UU No. 19 tahun 2016 tentang ITE, dalam Pasal 45A ayat (1), yang berbunyi, "setiap orang yang dengan sengaja dan tanpa hak menyebarkan berita bohong dan menyesatkan dipidana dengan pidana penjara enam tahun dan denda paling banyak Rp 1 miliar".

Pada tanggal 10 hingga 23 April 2020, Gubernur DKI Jakarta Anies Baswedan mengambil langkah untuk melakukan Pembatasan Sosial Berskala Besar (PSBB) setelah beredarnya kabar kasus Covid-19 telah merambah di 34 provinsi di Indonesia. PSBB pertama kali dilaksanakan di Kota Jakarta (WE Redaksi, 2020). Adapun tujuannya untuk meminimalisir menyebarnya penyakit Kedaruratan Kesehatan Masyarakat (KKM). Kegiatan dari pembatasan ini meliputi pembatasan kegiatan keagamaan, fasilitas umum, tempat kerja serta peliburan sekolah.

Namun, adanya perubahan dari aktivitas masyarakat menyebabkan sepi dunia usaha. Sehingga dirumah saja tidak selamanya bisa diberlakukan untuk menstabilkan perekonomian. Oleh karena itu pemerintah memberikan izin untuk kembali melakukan aktifitas bagi yang berumur dibawah 45 tahun, sekolahpun akan dibuka lagi pada Juli 2020. Akan tetapi aktivitas virus masih sama, menular cepat dan mudah, serta masih menyebar di tengah tengah masyarakat. Vaksinnya pun belum bisa ditemukan, sebab 
inilah tatanan hidup baru atau new normal akan diberlakukan. Wiku Adisasmita selaku Ketua Tim Pakar Gugus Tugas Percepatan Penanganan Covid-19 mengemukakan arti dari new normal yaitu merubah perilaku dalam melakukan aktivitas normal dengan mematuhi protokol kesehatan untuk menghambat adanya penyebaran Covid-19 (Haidar, 2020).

Era new normal ini juga berpengaruh pada lembaga pendidikan, bahwasannya lembaga pendidikan diharuskan untuk mampu beradaptasi dengan adanya perubahan dalam skala besar. Adapun perubahan akan banyak membutuhkan peran teknologi (Hetifah, 2020). Pada 15 Juni 2020 KEMENDIKBUD, KEMENAG, KEMENKES, KEMENDAGRI telah mengeluarkan KBA (Keputusan Bersama) terkait dengan kebijakan pendidikan dimasa Covid-19 dalam Era New Normal, berikut ringkasan isi.

1. Daerah yang berada pada zona kuning, orange, dan merah (429 kab/kota) dilakukan melakukan pembelajaran tatap muka disatuan pendidikan.

2. Sekolah di zona hijau ( $85 \mathrm{kab} /$ kota) dibolehkan melakukan pembelajaran tatap muka sesuai protokol kesehatan sangat ketat dengan persyaratan yang berlapis.

3. Sekolah akan dibuka secara bertahap, mulai dari sekolah tingkat SMP/SMA pada 13 Juli, SD 2 bulan sedangkan PAUD 2 bulan setelahnya.

4. Metode pembelajaran pada semua zona wajib dilaksanakan secara daring untuk mata kuliah teori. Untuk mata kuliah praktik, jika tidak dapat dilakukan secara daring maka diarahkan untuk dilakukan dibagian akhir semester.

5. Rektor di setiap perguruan tinggi pada semua zona hanya bisa mengizinkan kegiatan mahasiswa di kampus jika memenuhi protokol kesehatan.

Adapun penjelasan mendetail tentang pola pembelajaran pendidikan tinggi di tahun ajaran 2020/2021 (Era New Normal) terdapat pada kolom dibawah.

Tabel 4. Model Pembelajaran Perguruan Tinggi di Era New Normal

Tahun Tahun akademik pendidikan tinggi 2020/2021 tetap dimulai pada Akademik Agustus 2020, tahun akademik pendidikan tinggi keagamaan 2020/2021 2020/2021 pada September 2020.

Metode Pembelajaran di perguruan tinggi di semua zona wajib dilakukan Pembelajaran daring untuk mata kuliah teori, begitupun untuk mata kuliah praktik sedapat mungkin tetap dilakukan dengan daring. 


\begin{tabular}{ll}
\hline Aktivitas & Pemimpin perguruan tinggi pada semua zona hanya dapat \\
Prioritas dengan & mengizinkan aktivitas mahasiswa di kampus jika memenuhi protokol \\
protokol & kesehatan dan kebijakan yang akan dikeluarkan direktur jenderal \\
kesehatan & terkait untuk kegiatan yang tidak dapat digantikan dengan \\
& pembelajaran daring, seperti; \\
& -penelitian di laboratorium untuk skripsi, tesis, dan disertasi. \\
& -tugas laboratorium,praktikum,studio,bengkel, dan kegiatan \\
& akademik/vokasi serupa.
\end{tabular}

2. Proses Implementasi KMA No. 515 Tahun 2020

KMA No. 515 Tahun 2020 merupakan suatu kebijakan pada satuan pendidikan yang dilakukan di era saat ini, dimana kebijakan tersebut akan diterapkan pada PTKIN di Indonesia. Kebijakan tersebut dilakukan oleh pihak pemerintahan, hal ini selaras dengan Anderson (Arwildayanto et al, 2018) Policy implementation is the application by government's administrative machinery to the problems. Pelaku kebijakan adalah pemerintah, menurut kami dalam menerapkan kebijakan tersebut sudah tepat pada saat ini, dikarenakan pihak pemerintah ingin menyesuaikan tatanan pendidikan yang baru ini, terkhusus pada pendidikan tinggi. Proses implementasi hendaknya juga dapat memperhatikan tahapan-tahapan dalam implementasikan suatu kebijakan, sebagaimana dijelaskan oleh Charles O Jones dalam (Gaffar, 1997) memiliki tiga tahapan utama, yakni organization (organisasi), interpretation (interprestasi), and application (aplikasi/penerapan).

Pihak pemerintahan berusaha untuk menerapkan kebijakan terhadap pendidikan dengan mengeluarkan Keputusan Menteri Agama (KMA) Nomor 515 Tahun 2020 yang berkaitan dengan Keringanan Uang Kuliah Tunggal (UKT) untuk Perguruan Tinggi Keagamaan Negeri (PTKN) yang terdampak COVID-19, ditandatangani oleh Fachrul Razi (Menteri Agama Republik Indonesia) pada Jumat 12 Juni 2020. Dimana selanjutnya, Kamarudin Amin selaku Plt Dirjen Pendidikan Islam mengemukakan dibuatnya KMA ini sebagai bentuk respon atas dampak pandemi COVID-19 bagi mahasiswa PTKN, memberi keringanan kepada pihak yang membiayai, untuk kelancran dalam membayar UKT serta meminimalisir angka putus kuliah. Dipaparkan lagi bahwa KMA diberikan sebagai mandat untuk para Rektor PTKIN dalam memberikan mekanisme keringanan UKT, dan diharuskan untuk memberi laporan pelaksanaa keringanan tersebut kepada Direktur Jenderal dengan batasan pada akhir semester (Muhammad, 2020).

Terkait surat plt dirjen yang dibatalkan tersebut, mulailah kami mendapati berita yang viral di twitter dengan tagar \#kemenagprank, dikarenakan kemenag membatalkan rencana 
pemberian keringanan $10 \%$ bagi mahasiswa PTKIN dengan seketika, yang mana tagar tersebut dilakukan atas dasar rasa kecewa para mahasiswa karena dibatalkannya surat plt dirjen Nomor B-752/DJ.I/HM.00/04/2020 pada tanggal 20 April 2020. Menanggapi kejadian tersebut, Fachrul Razi memberikan penjelasan bahwa ide memberikan keringanan uang 'bantuan' itu akan diambilkan dari dana APBN dari pos pendidikan kemenag, namun tiba-tiba dibatalkan karena keputusan dari Menteri Keuangan yang meminta untuk setiap kementerian memberikan bantuan dalam pandemi Covid-19 secara mendadak, terpotong sejumlah $\mathrm{Rp}$ 2,6 triliun (Muhammad, 2020).

Berdasarkan hal itu, maka tentunya menimbulkan beberapa dampak terhadap para mahasiswa PTKIN di Indonesia, seperti aksi-aksi perjuangan yang dilakukan oleh Mahasiswa UIN Walisongo, IAIN Kudus, IAIN Surakarta, UIN Sunan Ampel, IAIN Pekalongan, dan lain sebagainya, dimana para mahasiswa menghendaki adanya penerapan KMA No. 515 Tahun 2020 itu benar-benar terealisasikan pada setiap PTKIN. Oleh karena itu, kami akan membahas dampak positif dan negatif yang ditimbulkan terkait KMA tersebut yang telah terjadi.

3. Dampak Positif dan Negatif Bagi Mahasiswa PTKIN.

Pada implementasinya dari kebijakan pemerintah tersebut memberikan beberapa dampak positif dan negatif terhadap mahasiswa PTKIN, akan tetapi kebijakan tersebut tidak berlaku pada mahasiswa PTKIS di Indonesia, dijelaskan oleh (Rubini, 2020) yang merupakan wakil ketua II STAI Masjid Syuhada Yogyakarta dan juga anggota Kopertais IV bahwasanya terkait UKT/SPP pada perguruan tinggi swasta tersebut dikembalikan kepada setiap yayasan atau lembaga yang menaungi perguruan tinggi swasta tersebut, seperti beberapa perguruan tinggi swasta di Yogyakarta. Sehingga KMA tersebut tidak memberikan pengaruh terhadap dampak yang ditimbulkan pada para mahasiswa PTKIS.

Adapun pada perguruan tinggi islam negeri, KMA No. 515 Tahun 2020 tersebut sangat menentukan pembiayaan pada perkuliahan mahasiswa PTKIN, hal ini dapat dilihat secara bersama akhir-akhir ini begitu banyak aksi para mahasiswa PTKIN untuk memperjuangkan keputusan tersebut pada setiap universitasnya, salah satunya yang terjadi di UIN Sunan Kalijaga Yogyakarta. Berdasarkan keterangan yang diberikan Plt Rektor UIN Suka, Sahiron, pihaknya telah memberlakukan kebijakan penurunan level UKT sebelum pandemi Covid-19 melanda. Kebijakan itu disebut sebagai Banding UKT. Sahiron juga mengungkapkan bahwa "UIN Sunan Kalijaga sudah menerapkan Banding UKT setiap semester sebelum pandemi Covid-19. Di masa Covid-19 ini Banding UKT kita terapkan juga,".

Menurutnya, semua orang tua mahasiswa saat ini memiliki kesempatan yang sama untuk melakukan banding yang saat ini prosesnya tengah berlangsung hingga 5 Juli 2020. 
Sebagaimana tercantum dalam Surat Edaran Rektor, persyaratan untuk melakukan banding itu adalah sebagai berikut:

a. Soft file Surat Permohonan Penurunan UKT dari wali mahasiswa;

b. Soft file bukti pembayaran listrik bulan terakhir;

c. Soft file Kartu Keluarga (KK);

d. Soft file KTP wali mahasiswa dan surat pernyataan bermaterai menerangkan sebagai wali

e. Soft file KTM mahasiswa UIN Sunan Kalijaga;

f. Soft file Surat Keterangan Tidak Mampu dari pemerintah desa yang menerangkan nilai nominal pendapatan wali mahasiswa.

Sementara itu, untuk pengurangan nominal dan penundaan pembayaran UKT, Sahiron menerangkan bahwa pihaknya masih menunggu Keputusan Menteri Agama (KMA) yang sedang dikaji lebih lanjut dan akan segera diterbitkan. Meski begitu, UIN Suka telah menyiapkan sejumlah mekanisme jika nantinya sudah resmi diberlakukan. Sahiron mengatakan "Wali mahasiswa mengirim usulan penundaan pembayaran UKT kepada Rektor disertai alasan-alasannya dan berkas-berkas pendukungnya, pengiriman usulan dilakukan secara daring (e-mail), menandatangani surat perjanjian akan membayar UKT semester gasal paling lambat 30 Oktober 2020, dan penundaan pembayaran UKT ini (hanya berlaku) bagi mahasiswa lama,". Saat dikonfirmasi lebih lanjut mengenai kelompok mahasiswa lama yang disebutkan sebelumnya, Sahiron menyebut mereka mahasiswa yang masih terdaftar sebagai mahasiswa UIN Suka dan belum terkena drop out atau DO (CNN Indonesia, 2020).

Keringanan UKT melalui KMA Republik Indonesia No. 515 Tahun 2020 pada 12 Juni 2020 yang berisi tentang, "Keringanan Uang Kuliah Tunggal pada perguruan tinggi keagamaan negeri atas dampak bencana wabah Covid-19". Menghadapi kondisi pandemi saat ini, berbagai dampak yang ditimbulkan sangatlah besar, khususnya di bidang ekonomi, sosial, dan pendidikan seperti yang akan dibahas dalam artikel ini. Dunia pendidikan tingkat SD hingga SMA hanya mengalami permasalahan di bidang pembelajaran yang dilakukan serba online, akan tetapi berbeda pada jenjang Perguruan Tinggi yang memiliki masalah dari dampak pandemi ini di bidang ekonomi. Permasalahan pembayaran UKT yang masih bersifat tetap dengan pengalokasian fasilitas serta sarana dan prasarana kampus yang seharusnya dinikmati oleh mahasiswa tidak dapat dilaksanakan sebagaimana mestinya, bahkan biaya kebutuhan mahasiswa bertambah ketika semua pembelajaran menggunakan media dalam jaringan (daring) yang membutuhkan kuota internet dan jaringan wifi yang memakan biaya tambahan bulanan yang cukup besar. Sedangkan biaya pembayaran UKT bersifat tetap dan perekonomian orang tua atau wali mahasiswa sebagian besar terdampak pandemi dan mengalami penurunan 
pendapatan. Hal tersebut membuat kalangan mahasiswa dengan perekonomian rendah hingga sedang merasakan keberatan dengan kebijakan ini.

Plt. Direktur Jenderal Pendidikan Islam, Kementerian Agama Kamaruddin Amin mengatakan, "UKT Mahasiswa Baru tahun akademik 2020/ 2021 telah ditetapkan berdasarkan KMA 1195/2019 tertanggal 27 Desember 2019”. Merespon kondisi dan situasi yang sedang terjadi terkait penyebaran virus Covid-19 memaksa Kementerian Agama untuk mempertimbangkan kebijakan pembayaran UKT mahasiswa. Berbagai isu muncul terkait UKT yang dikatakan naik, sehingga desas-desus berita tersebut sempat meresahkan mahasiswa padahal isu tersebut tidak benar sama sekali. Selain itu, sempat beredar adanya pemotongan UKT 10\% yang kemudian ditarik kembali, itulah beberapa rumor yang muncul di Era pandemi.

Pada poin ketujuh KMA No. 515 yang berbunyi, "Rektor atau Ketua PTKN menetapkan mekanisme pelaksanaan keringanan UKT pada perguruan tinggi keagamaan negeri sebagaimana yang dimaksud pada Diktum KESATU”. Atas kebijakan inilah kemudian muncul berbagai dampak terhadap kalangan mahasiswa, berikut beberapa dampak yang ditimbulkan setelah dikeluarkannya KMA No. 515 yang menyerahkan prosedur dalam pembayaran UKT masing-masing PTKN kepada Rektor:

A. Dampak positif

1) Mahasiswa dengan perekonomian rendah yang terdampak Covid-19 terbantu.

Ada respon positif mahasiswa yang memenuhi sosial media dengan menunjukkan kegembiraannya melalui postingan di sosial media yang menyatakan rasa syukur karena terbantu dengan adanya keringanan UKT menyambut era new normal ini.

2) Pengalokasian dana yang seharusnya dianggarkan dari UKT dalam sarana dan prasarana di kampus digunakan sesuai tujuannya.

Kebijakan beberapa kampus yang menyatakan adanya subsidi kuota internet untuk mahasiswanya sebagai bentuk pengalokasian dana peralihan ke pengalokasian era new normal menjadi kabar baik selanjutnya untuk mahasiswa yang disambut dengan kegembiraan.

3) Meringankan biaya studi di kampus.

Biaya studi di kampus yang lebih banyak, semisal untuk biaya hidup sehari-hari, seperti: sewa kos atau kontrakan, makan, uang bensin maupun uang jajan. Akan tetapi dengan adanya KMA tersebut membuat biaya studi di kampus terkurangi dan lebih sedikit dikeluarkan saat ini, karena sebagian besar mahasiswa berada di rumah dan biaya sewa kos pun mendapat potongan. 
4) Pembelajaran lebih fleksibel karena dilakukan di rumah masing-masing sehingga lebih nyaman sesuai standar kenyamanan mahasiswa.

Berdasarkan pengalaman selama daring, beberapa mahasiswa yang kurang percaya diri dalam pembelajaran dan ikut serta dalam diskusi menjadi lebih aktif, hal ini dikaitkan dengan kondisi mereka ketika di kampus yang terkadang banyak hal yang mengganggu, seperti tempat yang panas atau yang lainnya. Sehingga biaya UKT yang dibayarkan tidak sia-sia dengan peningkatan keaktifan mahasiswa.

B. Dampak negatif

1) Syarat dan ketentuan keringanan hanya berlaku bagi pihak mahasiswa yang terdampak Covid-19 dengan bukti surat PHK atau surat kematian orang tua dari mahasiswa dan sejenisnya, padahal sebagian besar orang tua atau wali mahasiswa bukan merupakan anak pegawai/ karyawan.

Kenyataan lapangan mengatakan bahwasannya sangat sulit mendapatkan keringanan UKT, padahal masalah ini sangat urgent untuk diselesaikan, mengingat mahasiswa juga memiliki tanggung jawab lain yang memberatkan antara lain biaya kos dan biaya hidup lainnya. Padahal pada kenyataannya seluruh pihak terdampak Covid-19 mayoritas mahasiswa menginginkan pemotongan UKT semestinya bersifat keseluruhan tanpa syarat apapun, karena biaya yang semestinya dialokasikan dari UKT tidak berjalan sesuai implementasinya dari ofline menjadi online (Hetifah, 2020).

2) Fasilitas kampus yang seharusnya ditujukan untuk mahasiswa tidak terpakai.

Pembelajaran via daring benar-benar mengubah sarana dan prasarana kampus, seperti lab komputer, wifi, perpustakaan dan fasilitas lainnya yang semestinya dinikmati mahasiswa, kini tidak lagi dapat diunakan sebagaimana mestinya. Dari kenyataan inilah mahasiswa mengeluhkan biaya yang ditanggung dalam UKT.

3) Prosedural pengajuan keringanan UKT yang cenderung rumit seperti persyaratan hendak mendaftar ulang, membuat mahasiswa semakin sulit.

Setelah banyaknya demonstrasi mahasiswa yang dilakukan di beberapa kampus yang ada di Indonesia baik desakan melalui media online melalui pamflet yang membanjiri sosial media yang bertuliskan, "Kementerian Agama menyebarkan hoax dengan menarik kebijakan pemotongan UKT". Selain itu dengan secara langsung mencorat-coret dinding kampus yang menuntut pemotongan UKT seperti yang dilakukan mahasiswa di salah satu perguruan tinggi negeri daerah Semarang, kemudian aksi-aksi yang dilakukan mahasiswa merespon rumor munculnya 
kebijakan kenaikan UKT, selanjutnya potongan UKT sebesar 10\% yang sempat ditarik, dan yang terakhir pemotongan UKT sebesar $15 \%$.

Kegembiraan sesaat dirasakan mahasiswa, denga keputusan akhir ini, namun tidak sepenuhnya karena kebijakan tersebut disandingkan dengan persyaratan yang begitu banyak. Seperti yang ditetapkan di salah satu perguruan tinggi Islam negeri di Pekalongan yang memuat syarat dan ketentuan mengajukan keringanan UKT yang berjumlah belasan. Hal ini tentu semakin merepotkan mahasiswa apalagi di kondisi yang serba sulit saat ini, kebijakan ini tentu tidak jauh berbeda dengan PTKN lainnya. Problem inilah yang menjadi kelanjutan keluhan mahasiswa kembali dan beredarlah di sosial media sebuah gambar yang bertuliskan "Rektor kenyang, menikmati uang mahasiswa". Gambar tersebut dibuat sebagai respon dari kebijakannya membuat mahasiswa geram dengan persyaratan yang rumit.

4) Pembelajaran yang dilakukan serba daring akan membuat mahasiswa semakin individual, hal ini disebabkan karena jarak antar mahasiswa.

Ketika di kampus mahasiswa dapat lebih berleluasa membuat forum-forum kecil untuk berdiskusi, berbeda dengan saat ini karena menyulitkan dan menggunakan aplikasi juga memiliki keterbatasan tersendiri seperti keberadaan kuota dan ketersediaan jaringan dengan sinyal yang lancar. Hal ini menyebabkan banyak mahasiswa yang menjadi semakin individualis.

5) Pembelajaran yang bersifat praktik akan lebih sulit dilaksanakan.

Pada mahasiswa semester bawah mungkin tidak terlalu bermasalah karena sebagian besar pembelajaran berupa teori, akan tetapi pada mahasiswa semester menengah hingga atas akan sangat terganggu karena banyaknya praktik yang harus dilaksanakan seperti Micro Teaching, PPL, KKN, Praktikum di laboratorium, dan praktik yang lainnya yang lebih banyak dilakukan sebelum siding skripsi dan prosedur lainnya.

6) Pembelajaran di rumah dinilai kurang efektif, karena tidak dapat dijauhkan dari kesibukan pekerjaan di rumah masing-masing mahasiswa.

Ketika di kampus mahasiswa berkumpul menjadi satu dan melupakan urusan pekerjaan di rumah sejenak, sehingga fokus pada pembelajaran. Sedangkan ketika di rumah banyak hal yang mengganggu, seperti mebantu orang tua, melakukan pekerjaan rumah yang tidak etis jika ditolak dan diacuhkan. Hal ini membuat pembelajaran terganggu dan dinilai kurabng efektif, sesuai yang dituturkan oleh beberapa mahasiswa selama daring. 
7) Jaringan internet di masing-masing daerah juga berbeda, hal ini menyebabkan mahasiswa banyak yang terhambat mengikuti kuliah dengan metode daring.

Ketika di kampus jaringan internet yang dibilang lancar dan terpusat membuat seluruh mahasiswa dapat mengikuti pembelajaran dengan llancar dan sesuai. Keadaan ini berbeda dengan mode daring yang tidak terjamin ketersediaan jaringan dengan sinyal yang lancar. Hal ini kembali meresahkan mahasiswa sehingga menuntut kebijakan subsidi kuota dari biaya UKT agar dapat menyediakan jaringan yang sesuai.

\section{SIMPULAN}

Berdasarkan paparan yang telah kami jelaskan, maka dapat diambil kesimpulan bahwa KMA No. 515 Tahun 2020 menimbulkan banyak kontroversi negatif daripada positif nya dalam implementasinya terhadap mahasiswa PTKIN, oleh karena itu segala keputusan yang ingin ditetapkan sebaiknya lebih dikaji secara lapangan jika ingin diterapkan. Harapan kami semoga artikel ini dapat menjadi bahan kajian tambahan bagi pelaku pembuat kebijakan terkait pendidikan di Indonesia, dan dapat menjadi referensi bagi peneliti selanjutnya.

\section{REFERENSI}

Abdul Fahmi, Rifki. 2020. "Kemenag Keluarkan KMA yang Berisi Pemberian Kwringanan UKT di PTKN, Online. Tersedia: https://prfmnews.pikiran-rakyat.com/nasional/pr13565667/kemenag-keluarkan-kma-yang-berisi-pemberian-keringanan-ukt-di-ptkn yang direkam pada 16 Juni 2020 11.27 WIB, (Juni 2020)

Anik Mayani, Nuh. 2020. “Tantangan Dan Solusi Pembelajaran Di Masa Pandemi Covid19”, Power Point pada Seminar Online Masa Pandemic, Jakarta.

Arwildayanto, Arifin Suking, and Warni Tune Sumar, 2018. "Analisis Kebijakan Pendidikan: Kajian Teoretis, Eksploratif, dan Aplikatif”. Bandung: CV Cendekia Press.

Basseti, Matteo, Antonio Vena, and Daniel Roberto Giacobbe. 2020. "The Novel Chinese Coronavirus (2019-nCoV) Infections: Challenges for Fighting the Storm”. European Journal of Clinical Investigation, Vol.50 No.3/P 1.

CNN Indonesia. 2020. “Terkait Corona, Kemenag Kaji Opsi Kurangi UKT di Kampus Islam”, (Jakarta), diakses pada Selasa, 09 Juni 2020 pukul 05:20 WIB.

Du Toit, Andrea. 2020. “Outbreak of A Novel Coronavirus”, Nature Reviews: Microbiology, Vol18/P 123.

Fahmi, Muhammad. 2016. "Pengembangan Sistem Penentuan Uang Kuliah Tunggal dengan Metode Fuzzy C-Means”, Skripsi. Malang: UIN Maulana Malik Ibrahim. 
Gaffar, Afan. 1997. "Publik Policy: State Of The Disipline, Model and Proses”. Yogyakarta: Pasca Sarjana Universitas Gajah Mada.

Huang, Chaolin, Yeming Wang, et al. 2020. "Clinical Features of Patients Infected With 2019 Novel Coronavirus In Wuhan,China”. Lancet Publishing Group, Vol 395/P 497.

Ilman Nafi'an, Muhammad. 2020. "Sempat Batal, Kemenag Terbitkan Kembali Keputusan Diskon Uang Kuliah di PTKN", Online, Tersedia: https://m.detik.com/news/berita/d5054836/sempat-batal-kemenag-terbitkan-kembali-keputusan-diskon-uang-kuliah-diptkin yang direkam pada 15 Juni2020 20.42 WIB, (27 Juni 2020).

Keputusan Bersama (KEMENDIKBUD, KEMENAG, KEMENKES, KEMENDAGRI), 15 Juni 2020.

Keputusan Menteri Agama (KMA) Nomor 515 Tahun 2020, Tentang “Keringanan Uang Kuliah Tunggal Pada Perguruan Tinggi Keagamaan Negeri Atas Dampak Bencana Wabah COVID-19”.

Khasanah, Dian Ratu Ayu Uswatun, Hascaryo Pramudibyanto, and Barokah Widuroyekti. 2020. "Pendidikan Dalam Masa Pandemi Covid-19". Jurnal Sinestesia, Vol. 10 No.1/41.

Lu, Hongzhu. 2020. "Drug Treatment Options For The 2019-New Coronavirus (2019-n CoV)”. Bio Science Trends, Vol.14 No.1/P 69.

Munir. 2009. "Pembelajaran Jarak Jauh Berbasis Teknologi Informasi Dan Komunikasi”. Bandung: CV Alfabeta, CV.

Nishiura, Hiroshi, Sung-Mok Jung, et al. 2020. "The Extent of Transmission of Novel Coronavirus In Wuhan China 2020”. Journal of Clinical Medicine, Vol.9 No.2/P 2.

Rais, Haidar. 2020. "Banyak yang Singgung Soal 'New Normal', Berikut Penjelasan Lengkapnya”. [Online]. Tersedia: https://prfmnews.pikiran-rakyat.com/gaya-hidup/pr13390558/banyak-yang-singgung-soal-new-normal-berikut-penjelasanlengkapnya?page=all yang direkam pada 29 Mei 202012.50 WIB.

Ren, Li-li, Yeming Wang, et al. 2020. "Identification of A Novel Coronavirus Causing Severe Pneumonia In Human: A Descriptive Study”. Chinese Medical Journal, Vol.133/P 1015.

Respati, Titik dan Hilmi Sulaiman Rathomi. 2020. KOPIDPEDIA"Bunga Rampai Artikel Penyakit Virus Korona (COVID-19)”. Bandung: P2U Unisba.

Rothan, Hussin A and Siddappa N Byrareddy. 2020. "The Epidemiology and Pathogenesis of Coronavirus Disease (COVID-19) outbreak”. Journal of Autoimmunity,109:102433/P 1.

Rubini. 2020. "Kebijakan KMA No. 515 Tahun 2020 terhadap PTKIS”. Hasil wawancara pribadi: 5 Juni 2020, Via WhatsApp.

Sjaifudian, Hetifah. 2020. "Alokasi Pembiayaan Dan Persiapan Lembaga Pendidikan Memasuki Fase New Normal”. Power Point pada Webinar Fakultas Pendidikan Universitas Gorontalo, Gorontalo. Pada hari Jum'at, 19 Juni 2020. 
Undang-Undang Nomor 19 tahun 2016 tentang Perubahan atas Undang Undang Nomor 11 tahun 2008 tentang Informasi dan Transaksi Elektronik (ITE).

Wang, Weier, Jianming Tang, and Fangqiang Wei. 2020. "Updated Understanding of The Outbreak of 209 Novel Coronavirus (2019-nCoV) in Wuhan China". Journal of Medical Virology, Vol.92 No.4/P 441.

WE Online. 2020. “Anies: Jakarta Jadi Kota Pertama Terapkan PSBB”. [Online]. Tersedia :https://www.google.com/amp/s/amp.wartaekonomi.co.id/berita280515/anies-jakartajadi-kota-pertama-terapkan-psbb yang direkam pada 10 April 202008.23 WIB.

Worldometer. 2020. "COVID-19 CORONAVIRUS PANDEMIC:Reported Cases and Deaths by Country, Territory, or Conveyance". [Online]. Tersedia: https://www.worldometers.info/coronavirus/\#countries yang direkam pada June 26, 2020 23:26 GMT,(Juni 2020).

Yuliana. 2020. “Coronavirus Diseases (Covid-19): Sebuah Tinjauan Literatur”. Wellness and Healthy Magazine Journal, Vol.2 No.1/Hal 187-189.

Yunus, Nur Rohim \& Annissa Rezki. 2020. “Kebijakan Pemberlakuan Lockdown Sebagai Antisipasi Penyebaran Corona Virus Covid-19”. SALAM: Jurnal Sosial \& Budaya Syar'i, Vol.7 N0. 3/Hal 228- 230.

Zhao, Shi, Qianyin Lin, et al. 2020. "Preliminary Estimation of The Basic Reproduction Number of Novel Coronavirus (2019-n CoV) in China from 2019 to 2020: a Data-Driven Analysis in the Early Phase of The Outbreak". International Journal of Infectious Diseases,92/P 214-217.

Kustandi, Cecep \& Robinson Situmorang. 2013. "Pengembangan Digital Library Sebagai Sumber Belajar". Perspektif Ilmu Pendidikan, Vol. 21 Th.XVIII/Hal 61. 